\title{
日本線虫学会第 2 回大会講演要旨（一般講演）
}

\section{科学技術庁研究交流センター（茨城県つくば市）1994年 5 月 9 日〜 10日}

\author{
Abstracts of Papers Presented at the Second Annual Meeting of \\ the Society in Tsukuba, May 9-10, 1994
}

宾田幸男（群馬農試）：尾瀬地域の土壤線虫相調 查：予報. SHISHIDA, Yukio (Gunma Agr. Res. Cent.): Soil nematode fauna of Oze district: a preliminary report.

わが国では、一地域の土壌線虫相調査例は極め て少ない。演者は、1989年と1991年に尾瀬が原周 辺の山地の土壤線虫相を調査する機会を得たので、 これまでに同定しえた種について、若干の形態学 的・動物地理学的知見を報告する。DORYLAIMIDA. Mononchus truncatus: 水っぼい所 を好む。恐らくは日本に広く分布。Coomansus zschokkei: Rus., Switz., Austri., Pol. 冷涼な地域。 Mylonchulus ubis: N. Z. 群馬県内では検出頻度は 高い。Iotonchus vorax: N. Amer. 二番目の検出 記録。湿地に棲息。I. risoceiae: Bras., Hawaii, Oahu,Maur., Ind. 群馬県内山地。Labronema sp.: Eur.の山地に分布する。L. stechlinense に近縁。 Chrysonemoides holsaticus: 世界的に検出の少な 认属。旧北区山地帯に分布。ARAEOLAIMIDA. Anaplectus submersus: N. Amer., Hol., 台湾。本 州中部ではほとんどが本種。A. granulosus: 汎世 界種のようであるが、日本での検出は稀。 Aphanolaimus seshadrii: Ind., 台湾。日本・台湾 ではほとんどが本種らしい。多数の未記録・未記 載種を検出。今年度より本格的な調査に入る予定 である。

中澤和則（群馬県中之条町立第五小学校）：群馬茨城の湿土壌より分離した Mononchus trunatusgroupについて. NAKAZAWA, Kazunori (Na- kanojo 5th Elementary School, Gunma): On the Mononchus truncatus-group collected from bog soil in Gunma and Ibaraki.

群馬の湿地土壊および茨城の水田土壤から分離 したMononchus truncatus-group に属する雌に ついて、分類学的検討を行った。計測值および形 態から、以下のことが示唆された。1）53個体は 尾の長さから、2 つの集団にはっきりと分けられ る。2 ) apex of dorsal tooth の位置は、尾の長 い集団では変異が小さく、24〜32\%の範囲にある が、尾の短い集団では異変が大きく $16 〜 34 \%$ の幅 がある。 3 ) transverse rib の位置は、口腔が長 了 なると、相対的に前になる傾向があるが、尾の長 い方の集団では全個体で rib の位置が apex of dorsal tooth より前方にあり、M. truncatus に属 すると考えられる。尾が短い方の集団では、rib が apex とほぼ同レベルか後方に位置し、M. pulcher に属すると考えられる。

平田賢司 (農環研)：日本産 Longidorus 属線虫の 2 種について. K. HiRATA (Natl. Inst. AgroEnviron. Sci.): Two species of Longidorus (Dorylaimida: Longidoridae) from Japan.

沖縄県石垣市のリュウキュウチクおよび栃木県 日光市のダケカンバの根圏土壤から検出した Longidorus 属 2 種の形態に関する知見について 報告する。リュウキュウチクから検出した 1 種の 計測值 $(\mathrm{n}=20)$ は、 $\mathrm{L}=5.97 \quad(5.31-6.85) \mathrm{mm}$ 、 $\mathrm{a}=117(106-130) 、 \mathrm{c}^{\prime}=1.10(0.99-1.18)$ 、歯針長 $=$ $172(158-181) \mu \mathrm{m}$ 、頭端から導環までの距離 $(\mathrm{GR})=$ 
$90.7 \quad(83.1-94.6) \quad \mu \mathrm{m}$ 、尾長 $=40.2 \quad(35.3-46.3)$

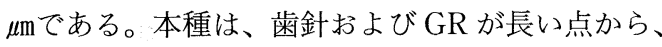
L. litchii XU \& CHENG, 1992 およびカラマツから 検出した L. sp. (平田、1994) と近似するが、尾 が長く（vs. 28.0（25.5-32.0） $\mu \mathrm{m}$ 抢よび $29.5(26.0-33.1) \mu \mathrm{m}) 、 c^{\prime}$ 值が大きく（vs. 0.70 (0.61-0.79) および0.74 (0.64-0.90)) 異なり、 さらに唇部にはくびれがなくその形も異なった。 ダケカンバから検出した1種の計測値 $(\mathrm{n}=10)$ は、 $\mathrm{L}=4.46 （ 4.21-4.84 ） \mathrm{~mm} 、 \mathrm{a}=87 （ 77-94) 、 \mathrm{c}^{\prime}=$ $0.89(0.76-0.99)$ 、歯針長 $=144(140-151) \mu \mathrm{m} 、 \mathrm{GR}=$ $80.0(75.5-83.7) \mu \mathrm{m}$ 、肛閏部体幅 $=$ 36.4 (33.5-38.0） $\mu \mathrm{m}$ である。本種は、歯針・GR の長さおよび唇部の形とくびれがある点から、L. fangi XU \& CHENG, 1990に近似している。しか し、本種は L. fangi に比べて肛門部体幅が小さく

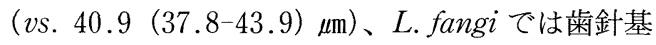
部が叉状となり、これらの点が相異した。

金 知仁 (韓國 農技研) ・皆川 望 (日本 農環 研）：韓國におけるネグサレセンチュウの發生お よび種について. KIM, Ji-In（Agr. Sci. Inst., Korea) \& N. Minagawa (Natl. Inst. AgroEnviron. Sci., Japan): Taxonomy and distribution of root-lesion nematodes in Korea.

韓國におけるネグサレセンチュウについての記 録は、1963年に小麥、大麥、ジャガイモ、サッマ イモ等で Pratylenchus pratensis 等 2 種が報告さ れたのが最初である。本研究は、最近、施設栽培 地帯の連作地で作物に大きな危害を與えている本 屬線蟲の種の同定を行うために行い、特に、施設 栽培を利用する花卉等を集中的に調査した。この 結果、韓國から既知の 3 種と末記載種（新種）の 可能性のある4種の合計7種を檢出した。地域別に 發生状況を見ると、馬山地域を初めとして 8 地域 でP. penetrans が檢出された。特に馬山では、P. penetrans、P. coffeae、P. neglectus の 3 種の他、 P. sp. 2 (nr. P. subpenentrans) および $P$. sp.1 (nr. P. coffeae) が檢出された。昌原では $P$. sp. 3 (nr. P. pseudopratensis)、高陽では P.sp. 4 (nr.
P. delattrei)、春川では $P$. sp. 1 が檢出された。 作物別では、カーネーション、ガーベラ、バラ等 9 種類に發生が見られた。線蟲別では、 $P$. penetrans は全地域で檢出され、檢出された作物 は多様で花卉、觀葉植物等8作物であった。 $P$. coffeae は馬山等 5 地域でキク等 3 作物で檢出さ れた。P. neglectus は馬山、春川地域で檢出され た。また、P. sp. 1 は馬山（キク）と春川（ガー ベラ）で、P. sp. 2 が馬山（キク）、P.sp. 4 が高 陽（バラ、カンノンチク）で、さらにP.sp. 3 は 昌原（キク）で檢出された。種名未確定種につい ては本年に再調査を行い、正確な種の分類同定を 行う予定である。

中園和年 (国際農研セ) ・YuLIANTORO B. (マラン 食用作物研）・CHAERANI（ボゴール食用作物研）: ジャワおよび南西スラウェシにおける植物寄生性 線虫(予報)。 NAKASONO, K. (JIRCAS), Yuliantoro B. (MARIF) \& CHAERANI (BORIF): Plant parasitic nematodes in Java and south west Sulawesi, Indonesia (Preliminary report).

インドネシア農業研究開発庁と農林水産省国際 農林水産業研究センターとの共同研究プロジェク トの一環としてインドネシアの伝統的栽培方式で ある田畑輪換栽培围場（以下「輪換地」）と純畑作 ないし樹園地の線虫相を調査比較し、田畑輪換方 式が線虫相および密度に及ぼす影響をさぐろうと した。調査は 7-9月の乾季に行い、ダイズなどの 畑作物ないし野菜、果樹類の栽培された輪換地、 純畑地ごとに標本土を取り、200 g のサブサンプル から篩いわけ一ベルマン法（変法）により線虫を 分離して検鏡した。分離検出された植物寄生性線 虫の種類（属）相は水田線虫の Hirshmanniella spp. を除いて輪換地と純畑地の間で大きな差異 はなく、主要属として双方から共通的に Helicotylenchus spp.、Rotylenchulus spp.、 Pratylenchus spp. Meloidogyne spp.、Tylenchor hynchus spp.、Criconemella spp.、Rotylenchus spp. および近縁属が検出された。ただし、田畑輪 
換の行われない永年的作物土㗒（サトウキビや果 樹など）からはしばしば Xiphinema spp. が検出 され、特徵的であった。

西澤 務 (日植防研究所) : サクラ(ソメイヨシノ) に寄生するネコブセンチュウについて. NISHIZAWA, T. (Inst. Jpn. Pl. Prot. Asso.): Meloidogyne spp. parasitic to flowering cherry tree, Prunus yedoensis.

タフト大統領夫人の要請により、1909年に日米 親善のシンボルとして尾崎東京市長からワシント ンD.C.宛てに送られた第一便の 2,000 本のサクラ 苗木は、N.A. CoBB らによる検疫の結果、ネコブ センチュウ (Heterodera radicicola) を含む各種の 病害虫に高率に侵されていたことから全株が焼却 処分され、かつこの一件が同国における植物検疫 法制定の契機となった、という史実がある。その ときのネコブセンチュウの種は果して何であった だろうか? 気掛かりなところである。国内での確 かな記録として、サクラに寄生するネコブセン チュウには M. mali と M. suginamiensis がこれ までに報告されている。たまたま当研究所構内の $M$. incognita 高密度围場内のサクラ樹の根系か ら M. incognita ではなく M. mali のみの寄生が 認められたことから、サクラ実生苗を用いてネコ ブセンチュウ種に対する反応を調べた結果、上記 の二種に加えて M. incognita、M. javanica およ び $M$. arenaria の 3 種もサクラに寄生・加害しう ることが判明した。

奈良部 孝(農研センター)：本邦産ジャワネコブ センチュウとアレナリアネコブセンチュウの分類 の再検討. NARABU, Takashi (Nat. Agr. Res. Centr.): Restudy of identification between Meloidogyne javanica and M. arenaria in Japan. 従来より用いられてきた同定法である会陰紋形 態により、ジャワネコブセンチュウと考えられた、 東北から沖縄まで71個体群線虫のアイソザイムを 調査した。エステラーゼの電気泳動パターンによ り、これら個体群は A1、A2、J3 (数字は検出バン
ド数）の 3 群に分けられ、本州から九州までの大 部分の個体群は $\mathrm{A} 2$ であり、 $\mathrm{A} 1$ は九州南部と沖縄 で 5 個体群、J3 は沖縄南部で 5 個体群、本州 (千 葉南部）で 1 個体群検出された。寄生性の異なる 天敵細菌 Pasteuria penetrans 系統を用いて付着 試験を行ったところ、A1、A2 群は全て、A2 由来 の PPMJ 系統に親和性が認められ、J3 群は全く PPMJ には反応せず、サツマイモネコブセンチュ ウ由来の PPMI 系統に親和性が認められた。A1、 $\mathrm{A} 2$ 群の雄成虫の head cap は平たく幅広で、口針 節球は球根状で先端が閉じており、DGO 值が 4.9 〜6.4 $\mu \mathrm{m}$ であるのに対し、J3 群は head cap は狭く 盛り上がり、口針節球は先端が開き幅広で、DGO

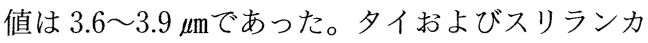
のジャワネコブセンチュウは全てわが国の J3 群 の性状に一致し、A1、A2 群は会陰紋形態以外はア レナリアネコブセンチュウの記述に一致した。以 上から、わが国でジャワネコブセンチュウとされ ていた線虫の大部分はアレナリアネコブセンチュ ウであり、ジャワネコブセンチュウは沖縄南部と 本州の一部で確認されているのみである。

皆川 望・吉田睦浩 - 水久保隆之 ${ }^{1}$ 竹原利明 ${ }^{2} \cdot$ 串 田篤彦 ${ }^{3} \cdot$ 立石 靖 $^{1} \cdot$ 白石啓義 ${ }^{4} \cdot$ 平田賢司（農環 研：現 ${ }^{\prime}$ 九州農試、農研センター、 ${ }^{3}$ 北海道農試、 ${ }^{4}$ 東北農試)：つくば地域の異なった土地利用条件 下に抢ける土壤線虫相の比較。 MINAGAWA, N., M. Yoshida, T. Mizukubo ${ }^{1}$, T.TAKehara ${ }^{2}$, A. Kushida $^{3}$, Y. Tateishi ${ }^{1}$, H. Shiraishi ${ }^{4} \&$ K. Hirata (Natl. Inst. Agro-Environ. Sci.; Pres. Add.: ${ }^{1}$ Kyushu Natl. Agr. Exper. Stn., ${ }^{2}$ Natl. Agr. Res. Centr., ${ }^{3}$ Hokkaido Natl. Agr. Exper. Stn., ${ }^{4}$ Tohoku Natl. Agr. Expr. Stn.): Comparison of soil nematode fauna under different land use in Tsukuba area.

つくば市およびその周辺の畑地、果樹園、林地 等土地利用条件の異なる 15 力所において 7 月から 9 月の夏季に土壌線虫相を調査した。 $1 \mathrm{~m}^{2}$ 当たり 地表から深さ $15 \mathrm{~cm}$ までの層に生息する線虫の密度 は、最も高いアカマツ林で1122万、最も低い公園 
のクリ樹の周辺で267万、15力所の平均は726万で あった。植物寄生性線虫の割合は、畑地では全線 虫の $5 \%$ 前後、林地ではそれより高く 10〜31\%で あった。桑園および雑草地ではピンセンチュウが 多く、植物寄生性線虫の割合は、それぞれ $63 \%$ 、 $50 \%$ となった。食菌性線虫の割合はナシ園で $33 \%$ と高く、これ以外は $4 \%$ から $19 \%$ であった。食細 菌性線虫は、畑地抢よびクリ園で $80 \%$ 前後と多く、 桑園および芝地で $25 \%$ 、28\%と低い以外は、50\% 前後であった。捕食性線虫は多くの場合 $1 \%$ 末満 であったが、芝地は $5 \%$ 強と高い割合を示した。 雑食性線虫の割合は、桑園およびナシ園で $3 \%$ 前 後と低く、畑地は $6 \%$ 台、草地、公園を含む樹木 のある庭園および林地では概ね $10 \%$ 前後と高い傾 向が見られた。

岩堀英明・二井一禎 (京大農)：Bursaphelenchus 属3系統の線虫に抢ける移動速度の比較.IWAHORI, Hideaki \& Kazuyoshi FutaI (Fac. Agr., Kyoto Univ.): Comparison of moving velocity among three nematode isolates of Bursaphelen. chus.

これまでにいくつかの報告において、マツノザ イセンチュウの病原性とその樹体内での運動性が 深く関わっていることが示唆されてきた。そこで 本研究では、Bursaphelenchus 属 3 系統の線虫の 移動速度が、線虫密度や温度にどのように影響を 受けるかを調べ、病原性との関わりについて若干 の考察を行った。密度依存性を調べる実験では、 非病原性の B. mucronatus $\mathrm{M}$ 系統において全般 に最も高い移動能力が示されたが、同じく非病原 性の B. xylophilus $\mathrm{S} 0$ 系統は、用いた 3 系統の中で 際立ってその移動速度が遅く、S0 系統の非病原性 の一つの原因と考えられた。病原性の B. xylophilus S1 系統の移動速度は低密度において $\mathrm{S} 0$ 系 統とほぼ同じくらいであったが、線虫密度が高く なるにつれて急激に高まった。最も高密度時には、 全ての線虫系統において移動速度の低下がみられ た。温度依存性についての実験では、M 系統は低 温に扔ける移動速度が最も高く、S1 系統はこれに
続いた。 $\mathrm{S} 0$ 系統の移動最適温度は 3 系統の中で最 も高かったが、移動速度は S1、M 系統に比べてど の温度条件下でも低かった。移動ゼ口温度を比較 した結果においても、 $\mathrm{M}<\mathrm{S} 1<\mathrm{S} 0$ 系統の順に低 かった。また、移動ゼロ温度は発育ゼロ点よりも 低く、線虫は発育不可能な低温においても移動で きることが判明した。

M. R. ALI ・ 石橋信義・近藤栄造（佐賀大農）：イ ネクキセンチュウ (Ditylenchus angustus) の灰色 かび病菌（Botrytis cinerea）上での発育と繁殖. Ali, M. R., N. Ishibashi \& E. Kondo (Saga Univ.): Growth and reproduction of the rice stem nemtode, Ditylenchus angustus, on a fungal mat of Botrytis cinerea.

インド、バングラデシュ等でイネに大被害を与 えているイネクキセンチュウの発育や繁殖生態は、 まだ十分には明らかにされていない。本線虫は、 室内での隔離培養を条件とする農水省植物防疫所 の特別許可により、B. cinerea を餌としてその発 育と繁殖を $25^{\circ} \mathrm{C} て ゙$ 調べた。本線虫の卵は 2 細胞期 で産下され、72時間以内に幼虫期に達し、直ちに 孵化した。幼虫期間は、 2 期、 3 期、 4 期とも 2 日で、産卵後 9 日で成虫となった。繁殖は両性生 殖で、雌成虫は、成虫化後 1 日目から産卵を開始 した。卵から卵までの 1 世代日数は約10日であっ た。1 頭の雌成虫を 3 日毎に新鮮な B. cinerea の 菌叢上に移し、このとき数頭の若い雄成虫を供給 して産卵数を計測した。1 日当たりの産卵数は、 産卵開始後 6 日から 9 日目にかけて最も多く、最 高 9 個となり、その後次第に減少して、15日目に は 0 となった。産卵全期間における 1 雌当たりの 平均産卵数は66個、1 日当たりの平均産卵数は 4.4 個であった。雌成虫は、産卵停止後約 2 日で死亡 し、平均寿命は産卵後27日であった。

水久保隆之 (九州農試) ・安達 宏 (ライオン陎) ・ 渋谷知子(農研セ)：キタネグセレセンチュウのラ イフサイクル（第 1 報）一毛状根実験系における 発育速度. Mizukubo, T. (Kyushu Nat. Agr. 
Expt. Stn.), H. Adachi (Lion Co., Ltd.) \&T. Shibuya (Nat. Agr. Res. Centr.): Life cycle of Pratylenchus penetrans by means of transformed root experiment system (Part 1).

植物寄生性線虫の生態研究における毛状根実験 系の利用には寄主植物の栽培を省略でき、扱う根 量が極めて少ない等の利点がある。演者らは千葉 県船橋市のニンジンに由来するキタネグサレセン チュウ（1 ㅇ 7 ずから確立した単雌系統）の雌各 1 頭を培地上のサニーレタス拉よびラジノクロー バの毛状根に接種し、各々20、25、27および $30^{\circ} \mathrm{C}$ で培養し、第 6 週まで週 2 回の頻度で回収して産 卵数、孵化幼虫数等を計数した。20、25、27およ び $30^{\circ} \mathrm{C}$ における最大産卵数は各々 $30 、 115 、 47 お よ$ び15個であり、回帰によって推定した接種後 2 週 間の産卵速度は各々 1.5、1.6、1.1および0.6個/

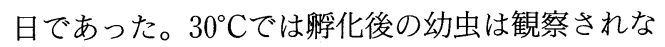

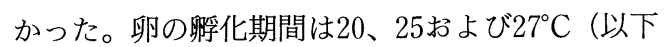
同順）で各々13.5、9.2および9.6日と推定され、 幼虫期間は各々19、18扔よび16日、また、卵から

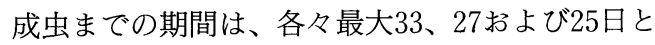

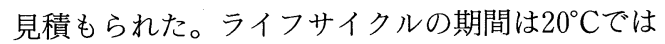
推定できなかったが、 $25^{\circ} \mathrm{C} て ゙ 28$ 日、 $27^{\circ} \mathrm{C} て ゙ も$ 最大 28 日と推定された。本研究の $20^{\circ} \mathrm{C}$ おび $25^{\circ} \mathrm{C} に お ~$ ける卵の粰化期間は杉の実生を用いた MAMIYA (1971)の $20^{\circ} \mathrm{C}$ よび $24^{\circ} \mathrm{C}$ の結果と一致したが、本 研究の $25^{\circ} \mathrm{C}$ のイフサイクルの期間は、後者の $24^{\circ} \mathrm{C}$ 結果（35日）より明らかに短かった。この 相違が実験系の相違に起因するものであるか否か について検討が必要である。

松尾和之・山本泰由・辻 博之（農研センター）： 乾燥牛筫の施用がダイズシストセンチュウ (Hetorodera glycines ICHINONE) の寄生に及ぼす 影響. Matsuo, K., H. Yamamoto \& H. Tsuji (Nat. Agr. Res. Centr.) : Effect of cattle feces application on the number of $H$. glycines famale adults in soybean.

各種資材の土垬（農業研究センター内戋場のダ イズシストセンチュウ污染土）への添加が、ダイ
ズ（T201； 根粒非着性系統）に対するダイズシ ストセンチュウの寄生に及ぼす影響を検討した。 ダイズの栽培は、グロースキャビネットを用いて 行い、温度条件は出芽 10 日までを $25^{\circ} \mathrm{C} 、 そ の$ 後 $30^{\circ} \mathrm{C}$ とした。日長は、12:12hrs とした。ダイズ出芽 14、21日後に、雌成虫の肥大が明らかに認識され る個体を計数した。乾燥牛䔬施用区では、出芽 12 日前後から本葉の黄化が見られ、出芽14日後のダ イズ根上の雌成虫寄生数は、無肥料区、化成肥料 区、ショ糖添加区を大きく上回る（24～34倍：対 無肥料区）值を示した。雌成虫寄生数とダイズの 根長、 $\mathrm{N}$ 含有率、土壌中の無機態 $\mathrm{N}$ 濃度との相関 は低かった。牛粪添加区の寄生数は乾燥牛䔬の添 加量が多いほど高い值を示した。牛䔬添加区での 化成肥料施用は寄生数を減少させた。出芽21日後 の調査でもほぼ同様な結果を得た。なお、牛䔬に よる持込みの可能性を検討したところ、滅菌土に 乾燥牛瞥を添加しても寄生は見られず、非滅菌土 に滅菌乾燥牛糞を添加すると顕著な寄生数の増大 が認められた。

小林義明・牧野孝宏・佐藤允通（静岡農試）・渥美 剛 (静岡西部農改)・皆川 望 (農環研)：センリヨ ウ栽培における Aphelenchoides fragariae の発生 と被害. Kobayashi, T., T. Makino, S. Sato (Shizuoka Agr. Exp. Stn.), T. Atsumi (Shizuoka Seibu Agr. Extension Stn.) \& N. MinagawA (NIASE): Occurrence and damage of Aphelenchoides fragariae on cultivated Chloranthus glaber.

静岡県湖西市において、切花用のセンリヨウが 約 6 ha栽培されているが、生育途中の落葉や株の 萎ちょう枯死に伴う生育不良が古くから問題に なっていた。演者らの一人牧野は1991年に落葉中 に多数の線虫を確認し、1993年に小林はこれが Aphelenchoides 属の線虫であることを認め、皆川 によりイチゴセンチュウ A. fragariae であると同 定された。落葉は梅雨期から秋雨期に多く、これ によって生育が抑制され着果茎が減少すると考え られた。落葉は10月にも多く、1月にも若干観察 
された。落葉が起こる葉は成葉で、一見正常に見 えるが、よく見ると葉の一部にわずかな褐変が認 められる程度であるが、落葉後に葉脈によって区 切られた被害部分が明瞭な葉枯れ症状を呈した。 落葉後の葉枯れ部分では、線虫密度が比較的早く 低下寸るようであり、10月および 1 月の調査にお いて、株元に発生する吸枝の頂芽やえき芽内に本 線虫のさまざまな発育ステージの外寄生が多数認 められ、芽内の幼葉の表皮に線虫によると考えら れる被害痕がごく普通に観察された。小林（未発 表）は A. ritzemabosi のキクにおける基本的な生 活環として、冬至芽内の外寄生 $\rightarrow$ 展開葉内での内 寄生 $\rightarrow$ 冬至芽内の外寄生を認めたが、本報告のセ ンリョウの A. fragarise の生活環もこれと共通す る部分が多く観察された。

大石剛裕・小林義明・池田二三高（静岡農試）・植 松徳雄 (静岡県東部農林) : 各種対抗植物による少 ツマイモネコブセンチュウおよびキタネグサレセ ンチュウ防除効果の実用的評価. OISHI T., Y. Kobayashi, F. Ikeda (Shizuoka Agr. Exp. Stn.) $\&$ N. Uematsu (Shizuoka Tobu Agr.Extension Stn.): Practical estimation of effects of treatments several antagonistic plants to Meloidogyne incognita and Pratylenchus penetrans.

演者らはヤマトイモのネコブセンチュウの防除 に対抗植物の利用を検討し、実用的にかなり高い 線虫防除効果を確認したが、今回はギニアグラス ‘ナツカゼ'、Crotalaria juncea、C. spectabilis、

Tagetes erecta、Sorghum bicolor ‘スダックス’に ついて、さらに、M. incognita を対照に砂土で効 果の確認を行った。その結果、約 3 ケ月対抗植物 を栽培した区では、対照のニンジン区に比べて有 意に土壌中の線虫密度が低下し、各対抗植物の根 内に抢ける侵入線虫数もニンジンに比べて少なく、 線虫の発育速度もニンジンに比べて著しく低かっ た。また別に、P. penetrans を対照に三島市の火 山灰土壤のダイコンの後作で、9 種の対抗植物と 裸地区を設けて約 3 ヶ月栽培後、ダイコンを作付
して収穫時に土壌中の線虫密度とダイコンの被害 程度を調査した。その結果、Tagetes patula の 2 品 種は裸地に比べて有意に被害指数が低く、実用的 な防除効果が認められた。それ以外の植物（ギニ アグラス、C. juncea の 2 品種、C. spectabillis、 S. bicolor、Cessia torosa、野生種のエンバク）は 裸地区並みの被害度指数で実用的な防除効果は認 められなかった。

北上 達 (三重農技セ) ・奈良部 孝（農研セ）・ 安達宏（ライオン(秼)：天敵出芽細菌 Pasteuria penetrans のサツマイモネコブセンチュウ防除効 果. Kitagami, Tooru (Mie Agr. Res. Centr.), Takashi Narabu (Nat. Agr. Res. Centr.) \& Hiroshi ADACHI (Lion Co., Ltd) : Control of Meloidogyne incognita by Pasteuria penetrans.

出芽細菌 Pasteuria penetrans のうち、従来用い てきた PPMI-N（茨城県つくば市産）および付着 試験で最も優良と認められたPPMJ3-HS (沖縄県 竹富町産）の 2 系統を用いてサツマイモネコブセ ンチュウの防除効果を検討した。胞子を土㖶 $1 \mathrm{~g}$ 当たり $10^{5}$ (PPMJ3-HS のみ)、 $10^{4}$ おび $10^{3}$ 個と なるように蒸留水 $50 \mathrm{ml}$ に懸濁させ、線虫生息土袞 に処理した。土壌はベルマン法による線虫検出数 が340頭、26頭および 1 頭の黒ボク土壤を供試し た。各区反復なしとし、105個処理は初期線虫密度

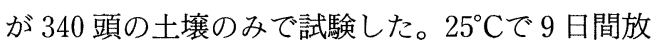
置後、トマト（品種：強力米寿）を定植した。 PPMJ3-HS の105個および104個処理では、定植55 日後のトマト根部に寄生した雌成虫での胞子形成 率が36〜 71\%に達したが、PPMI-N では11〜20\% であった。また、PPMJ3-HS では定植73日後の 2 期幼虫数は無処理比で $5 \sim 37 \%$ に減少し、胞子付 着率は $63 \sim 87 \%$ と高く、付着数も1.0～4.5個／頭 と多かった。PPMI-N では 2 期幼虫数は無処理比 で49〜 78\%であり、胞子付着率および付着数は 21〜35\%、0.3〜0.4個であった。なお、103個処理 では 2 系統とも雌成虫での胞子形成率および 2 期 幼虫への胞子付着数ともに低かった。 
佐野善一 (九州農試)・J. T. GASPARD (㑣ネマテッ ク)：出芽細菌によるサツマイモネコブセンチュ ウの産卵抑制. Zen-ichi SANO (Kyushu Nat. Agr. Expt. Stn.), J. T. GASPARD (Nematech Co. Ltd.): Suppressed egg-laying of Meloidogyne incognita by Pasteuria penetrans.

出芽細菌の線虫増殖抑制効果を解析するために、 ネコブセンチュウの発育や増殖に及ぼす影響を調 査した。鹿児島産の出芽細菌 (Pasteuria penetrans、以下「pp」) を接種・付着（付着率 98.5\%、付着数 4.3 )させたサツマイモネコブセン チュウ第 2 期幼虫 (Rase 1、以下「J2」) を30時間 ミニトマト (プリッツ) に接種、トマトは滅菌黒 ボク土壤 $250 \mathrm{~g}$ をれたポリポットに 1 本ずつ移 植、平均室温 $24^{\circ} \mathrm{C} 、 29^{\circ} \mathrm{C}$ おび $34^{\circ} \mathrm{C}$ の陽光人工気 象室で14時間日長で栽培、所定時間後にトマトを 取り出し、寄生した線虫の発育と産卵を調査した。 $\mathrm{pp}$ 無接種の健全な $\mathrm{J} 2$ を対照とした。pp 接種、無 接種間に線虫の発育の違いはなく、 $24^{\circ} \mathrm{C} て ゙ は$ 線虫

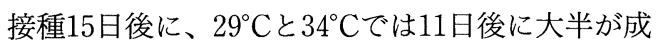

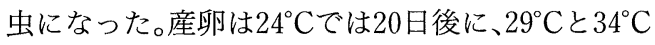
では14、15日後に観察され、有効積算温度では240 日度に相当した。卵数は、pp 接種区が無接種区に 比べて常に少なく、 pp による産卵抑制率 ( $1-\mathrm{pp}$ 接種区卵数/無接種区卵数) は、最大 $94 \%$ 、最小 $61 \%$ であった。pp 接種区では産卵雌の割合が低く、さ らに産卵雌当たりの卵数も少なかったことから、 出芽細菌は主に雌成虫の産卵阻止抢よび産卵抑制 によって線虫の増殖を抑制していると考えられる。

吉田るり子 (㑣ネマテック)・奈良部 孝（農研セ ンター)・J. T. GASPARD・川田弘志（侏ネマテッ ク)：連作によるP. penetrans の付着性変化. YoShIDA, R. (Nematech Co., Ltd.), T. NARABU (Nat. Agr. Res. Centr.), J. T. Gaspard \& H. KaWAdA (Nematech Co., Ltd.): Changes in Pasteuria penetrans attachment to $M$. incognita during tomato mono-culture

P. penetrans 胞子のサツマイモネコブセンチュ ウに対する防除効果は、既報（日線虫誌 23（2）、
1993）通り長期にわたって認められた。しかし、 3 作栽培後より、連作しているサツマイモネコブ センチュウに対して、P. penetrans の付着性の低 下が見られた。この傾向は徐々に強まり、付着抵 抗性線虫の増加によって、7 作目はネコブ指数が 防除目標としている水準「2」を超えた。一方、 このP. penetrans は、他で増殖したサツマイモネ コブセンチュウには連作開始時と同様の付着性を 示した。P. penetrans 付着抵抗性を示したサツマ イモネコブセンチュウには、わずかであるが $P$. penetrans の付着が認めらた。このP. penetrans 付き線虫を集積培養して得られた $P$. penetrans は、P. penetrans 付着抵抗性を獲得したサツマイ モネコブセンチュウに対して付着性を回復した。 また、自然界で見いだされたサツマイモネコブセ ンチュウに付着するP. penetransに付着抵抗性 を示すサツマイモネコブセンチュウ（奈良部ら 応動昆 1993）に対しても、集積より得られた $P$. penetrans は上記同様の付着性を示した。

松永禎史 - 石橋信義・近藤栄造（佐賀大農）：植物 寄生性線虫の根侵入に対する数種有用線虫の抑制 効果. MAtsunaga, T., N. Ishibashi \& E. Kondo (Saga Univ.) : Suppressive effect of several benefical nematodes on the root invasion of plant parasitic namatodes.

我々はスタイナーネマや菌食性線虫の大量施用 でネコブセンチュウによる被害の軽減を報告して きた。本実験ではキュウリ毛状根を用い、ペトリ 皿で植物寄生性線虫に対する抑圧効果を観察し た。Pratylenchus coffeae (P. c.) 、Meloidogyne incognita (M. i.) それぞれ 100 頭に対し、Steinernema carpocasae (S. c.) 、S. glaseri (S.g. )、 S. anomali (S. a. )、S. kushidai (S. k. )、 Aphelenchus avenae (A. a.) を、P.c.、M. i.と同 時、 2 時間前 - 後に同数、10、50、100倍施用し た。S.c.と A. a.は混合施用も試みた。植物寄生性 線虫の単独接種時の侵入数を 100 として、それぞれ の対照とした。有用線虫の施用頭数が増加するほ ぞ P.c.、M.i.の侵入率は低下した。最も侵入率が 
低下した組み合せは下表の通りである。

\begin{tabular}{|c|c|c|c|c|c|}
\hline \multicolumn{6}{|c|}{ 植物寄生性線虫のキュウリ毛状根への侵入率 } \\
\hline & $2 \mathrm{hr}$ 前施用 & & 同 & 時 施 & 用 \\
\hline & S. c. S. k & S. g. & S. a. & A. a. & S. c. + A.a. \\
\hline & $3.4 \quad 27.5$ & 12.9 & 14.0 & 4.1 & 22.0 \\
\hline M. c. & $2.4 \quad 29.5$ & 2.7 & 27.4 & 3.9 & 29.3 \\
\hline
\end{tabular}

清原友也・小坂 肇（森林総研）・伊藤進一郎（森 林総研関西)・田端雅進(森林総研四国) ・佐野 明 (三重県)：ヒゲジロキバチに寄生する線虫につ いて. KiyohaRA, T.,H. Kosaka (For. \& Forest Prod. Res. Inst.), S. Ito (Kansai Res. Ctr., For. \& Forest Prod. Res. Inst.), M. TABATA (Shikoku Res. Ctr., For. \& Forest Prod. Res. Inst. ) \& A. SAno (Mie Pref. Office) : On a nematode parasitic to a woodwasp.

キバチ類は、スギやヒノキ等の針葉樹に寄生し、 生立木の材部に星型の斑紋を形成して材価の低減 をまねく林業上重要な穿孔虫類である。今回、三 重県のスギ丸太から羽化したヒゲジロキバチ

(Urecerus antennatus) 16個体を解剖調查した結 果、その中の 4 個体から内部寄生性の雌線虫と幼 虫が検出された。この幼虫を、ヒゲジロキバチの 共生菌である Amylostereum chailettii 上で培養 すると菌食性の雌雄が出現し、その形態は Deladenus 属の特徵を示した。Deladenus 属の線 虫は、オーストラリアやニュージランドではキバ チ類の生物的防除に使われており効果をあげてい る。今後、わが国のキバチ類に寄生する線虫の種 の同定と寄主に及ぼす影響を明らかにする必要が ある。

真宮靖治・氏永 剛（玉川大農）：森林における Steinernema 属線虫分布実態の一事例. MAMIYA, Y. \& T. UjinAGA (Tamagawa Univ.) : An observation of distribution pattern of steinernamatids in forest soil.

玉川大学箱根演習林および玉川学園構内（町田 市）において、Steinerneme 属線虫の生息・分布実 態の解明、さらには植生や標高などの環境条件と
の関連性を明らかにすることを目的に調査を行っ た。植生状況や標高などの条件を考慮した調査区 を設定し、各調査区から採取した土壌について、 ハチノスッヅリガ幼虫を用いたトラップ法により 線虫検出を行った。箱根演習林における10調査区 (標高500〜 $1000 \mathrm{~m} 、$ 広葉樹林、スギ・ヒノキ人工 林、ササ地) のうち 6 調査区から Steinerneme 属 線虫が検出され、玉川学園構内の 2 調査区（ヒ） キ人工林、夕ケ林) にも Steinerneme 属線虫の生 息・分布が認められた。線虫が検出された調査区 では、時期を異にして行った 3 回にわたる調査で いずれも同じ線虫が検出されたことから、線虫検 出の再現性を確認することができた。箱根演習林 では調查区別に S. carpocapase およびS. feltiae にそれぞれ近似の種、また新種の可能性のある種 など少なくとも 3 種が検出された。玉川学園構内 に分布していたのはS. feltiae に近似の線虫で あった。線虫の分布に関しては、標高によって検 出された種が異なったこと、火山灰土壤における 生息であること、線虫の生息に $\mathrm{A}$ 。層発達の影響が 考えられることなど、環境条件との関連性が示唆 された。本調査の結果は、森林土壤中における線 虫分布の実態を生態学的視点において解析するこ とで、線虫が森林生態系において果たす役割の解 明へと研究を発展させる手がかりを与えた。

吉田睦浩 (農環研)：西南日本太平洋沿岸地域から 検出された Steinernema属線虫について. YoSHIDA, Mutsuhiro (NIAES): Steinematids from south-west Japan along the Pacific Ocean.

Steinernema 線虫の分布については、和歌山県 以西の太平洋沿岸地域における調査結果を属レべ ルで報告した(1993 応動昆大会)。本講演ではそ の後の調査結果を含めて、種レベルの検討結果を 報告する。沖縄県から静岡県に到る太平洋沿岸の 照葉樹林帯から多くの Steinernema 属線虫が検 出され、これらは感染態幼虫および雄成虫交接刺 の形態的特徵を基に、以下の 5 群に分かれた。 Pop. 1 (与那国島)：S. affinis の成熟感染態幼虫 の特徵である Terminal Spine を持つ感染態幼虫 
が、若干ではあるが見られた。したがって、感染 態幼虫の計測值および雄成虫交接刺の形態もほぼ 一致することから、本個体群はS. affinis と判断 される。なお、S. affinis は現在のところヨーロッ パから記録されているだけである。Pop. 2 (高知 県土佐清水市、東洋町、和歌山県日高町、串本町): 雄成虫交接刺の形態の変異パターンを基に $S$. kushidai と判断した。Pop. 3 (和歌山県美浜町)： 交接刺の形態が既知種とは異なるため一つの群と したが、所属は検討中。Pop.4 (愛知県渥美市)： 雄成虫の交接刺は典型的な S. feltiae の形態パ ターンを示した。Pop. 5 (鹿児島県佐多町、高知 県土佐清水市、室戸市、和歌山県串本町、愛知県 渥美市、静岡県御前崎町)：S. feltiae の感染態幼 虫の計測值パターンに類似するが、以下の点で Pop. 4 とは別種と判断される。(1)感染態幼虫の体 長および $\mathrm{b}$ 值、(2)雄成虫の交接刺の形態、(3)同所 的に分布すること。

伊藤賢治・奈良部 孝（農研センター）：タンパク 質電気泳動による昆虫病原線虫の種および系統の 識別. ITou, Kenji \& Takashi Narabu (Nat. Agr. Res. Centr. ): Use of enzyme phenotypes for identification of entomopathogenic nematodes.

4 種類 8 系統の昆虫病原線虫、Steinernema carpocapsae (All、DD-136、Mexican系統)、S. glaseri (N.J.、佐賀大分譲系統)、S. kushidai (Hamakita 系統)、Heterorhabditis bacteriophora (HP 88、 佐賀大分譲系統）のアイソザイムの差異を調べ、 これらの種および系統の識別を試みた。ハチミツ ガ幼虫から分離した昆虫病原線虫の感染態幼虫 1 万頭以上を $50 \sim 150 \mu 1$ の抽出液 $(20 \%$ Sucrose、 $2 \%$ Triton-X) とともに磨砕し、冷却遠心後、脂 質と沈澱を除去して泳動用サンプルとした。電気 泳動はポリアクリルアミドゲルを用い、一定電流 $(20 \mathrm{~mA})$ で行った。泳動後、リンゴ酸脱水素酵素 とエステラーゼの活性染色を行った結果、泳動パ ターンの差から、供試した 4 種の線虫を区別する ことができた。同種内の系統間を比較したところ、
S. glaseri の 2 系統間の差が明瞭であったが、S. carpocapsae の 3 系統間および H. bacteriophora の 2 系統間では差が明瞭ではなかった。しかし、 Ampholine ゲル (pH3.5〜9.5) を用いた等電点電 気泳動では、S. carpocapsae の Mexican 系統は 他の 2 系統とエステラーゼの泳動パターンが異な り、識別が可能であった。なお、ドッグフード培 地から分離した線虫には感染態幼虫以外のステー ジも含まれるため、ハチミツガから分離した線虫 とは異なる泳動パターンを示した。

㴊 通則 - 近藤栄造 - 石橋信義 (佐賀大農): 昆虫 寄生性線虫 Steinernema carpocapase の簡易無菌 培養と無菌線虫の感染性. FUCHI, M., E. KONDO $\&$ N. Ishibashi (Fac. Agri., Saga Univ.) : Simple axenic culture of entomopathogenic nematode, Steinernema carpocapsae, and its pathogenicity.

共生細菌を保有しない場合の Steinernematidae 科線虫の殺虫性を明らかにするため、 先ず、S. carpocapase を簡単に無菌培養する方法 を検討し、次いで、培養で得られた無菌線虫の感 染性を接種試験で調べた。1）ぺプトン、酵母抽 出物、肝臓の熱抽出物からなる C. elegans 用無菌 培地（A培地という。）を基本培地とし、この培地 7 に対してオリーブ油、大豆粉末などの混合物を 3 の割合で添加した培地 (B培地)、および $\mathrm{A}$ 培地 にオートクレーブ殺菌した八チミツガの終齢幼虫 を添加した培地（C培地）に硫酸アミカシン溶液 $(5 \mathrm{mg} / \mathrm{ml})$ を用いて無菌化した抱卵雌成虫あるい は遊離卵を接種し、 $25^{\circ} \mathrm{C} て ゙$ 培養した。その結果、

$\mathrm{A}$ 培地に比べて $\mathrm{B}$ 培地およびC培地上で増殖した 線虫数は、接種 2 週間後で、総線虫数は60〜106 倍、感染態幼虫数は35〜 72倍と著しく多くなった。 また、BおよびC培地上で発育した抱卵雌成虫の 体長は、ドッグフード培地で Monoxenic 培養し た抱卵雌成虫より有意に大きくなった。2) Monoxenic 培養で得られた感染態幼虫と無菌の 感染態幼虫のハチミツガ幼虫への侵入率数と殺虫 率をぺトリ皿を用いた接種試験 (50頭/ $6 \mathrm{~cm}$ ペトリ 
皿）で調べた結果、保菌線虫に比べて無菌線虫は、 線虫接種 6 時間後の侵入率が約 $1 / 2$ 、接種 48 時間 後の殺虫率が $1 / 16$ 以下の約 $7 \%$ となり、殺虫能力 は低かった。

王小冬・石橋信義・近藤栄造（佐賀大農）：Steinernema carpocapase の種維持戦略一感染性の経時 変化と感染線虫の性比. WANG, X. D., N. IsHIBASHI \& E. Kondo (Saga Univ.) : Species mainte nance strategy of Steinernema carpocapsae : post emergence infectivity and sex ratio of invading infective juveniles.

S. carpocapsae の種族維持機構を解明するため、 昆虫死体から遊出した感染態幼虫 (以下 $\lceil\mathrm{IJ} 」$ と略 す）の時間経過に伴う感染性の変化と、昆虫に感 染した線虫の性比を室内実験で調査した。八チミ ツガ幼虫の死体から遊出直後の IJ および $2 、 4 、$ 6、8 週間低温保存 $\left(8^{\circ} \mathrm{C}\right)$ した $\mathrm{IJ}$ をぺトリ皿内 のバーク堆肥の下層に接種した結果、表層まで上 昇して特異的感染行動である Nictating をしめし たIJ の比率は、それぞれ、13.2、17.7、33.1、 $38.8 、 58.2 \%$ となり、低温保存の期間が長くなる につれて高くなった。八チミツガ幼虫への感染率 も同様に、遊出直後 $11.4 \% 、 2$ 週間後 $29.1 \% 、 8$ 週間後 $51.6 \%$ と低温保存期間が長くなると高くな る傾向を示した。ペトリ皿を用いた接種試験で八 チミツガ幼虫に侵入した線虫の雄成虫の比率を調 査した結果、Nictating をしていない IJ を供した 場合は $37.5 \%$ 、NictatingしていたIJの場合に $54.6 \%$ 、バーク堆肥の下層に線虫を、上層に昆虫 を置いた場合は、70\%以上と高くなった。上述の 実験結果に基づき、本線虫の種族維持機構を考察 する。

帆足夏子・近藤栄造・石橋信義（佐賀大農）：昆虫 寄生性線虫 Steinernema carpocapase の発育と性 分化. HoAshi, N., E. Kondo, N. Ishibashi (Fac. Agr., Saga Univ.): Growth and sex differentiation of entomopathogenic namatode, Steiner. nema carpocapsae.
昆虫寄生性線虫 S. carpocapsae の成虫には、大 型の第 1 世代成虫と、小型の第 2 世代成虫の 2 型 がある。本研究では、Steinernema 属昆虫寄生性線 虫における繁殖戦略を明らかにする基礎として、 第 1 世代抢よび第 2 世代における生殖腺の発育と 分化の過程を調査した。ドックフード培地上で同 調培養した線虫について、発育ステージ別に形態 観察および体長と生殖腺の測定を行った結果、第 1 期幼虫の生殖腺は楕円形（長径約 $8 \mu \mathrm{m}$ ）で、そ の後、発育に伴い体軸方向に沿って伸長した。第 1 期幼虫、第 2 期幼虫および感染態 3 期幼虫では、 生殖腺の形態および大きさにおいて雌雄差は認め られなかったが、寄生型 3 期幼虫では性分化が明 瞭となり、雄では生殖腺前部が後方に反転するの に対して、雌では反転しないで伸長した。体長お よび生殖腺長は第 4 期幼虫および成虫化後に急速 に伸長した。第 1 および第 2 世代の雌成虫の生殖 腺長の差は、産卵前に有意でなかったが、産卵開 始後に有意となり、第 1 世代では体長の約 2 倍の $6.265 \mu \mathrm{m}$ 、第 2 世代では体長の約 1.4 倍の $2,334 \mu \mathrm{m} て ゙$ あった。また、成虫の体長と抱卵数の間に、第 1 世代では正の相関が認められたが、第 2 世代では 認められなかった。

田辺博司・山中 聡・武内克義（侏)エス・デイー エスバイオテックつくば研)・吉田睦浩（農環 研): 高知県産 Steinernema 属線虫より分離され た共生細菌の生理的性質および殺虫活性について。 TAnabe, Hiroshi, Satoshi Yamanaka, Katsuyoshi TAKEUChI (SDS Biotech K. K., Tsukuba Tech. Centr.) \& Mutsuhiro Yoshida (Nat. Inst. Agro-Environ. Sci.) : Physiolosical characteristics and insecticidal activity of the newly isolated bacterium from an entomopathogenic nematode, Steinernema sp., discovered from Kochi Prefecture, Japan.

高知県東洋町土壤より分離した Steinernema 属線虫（以下「KYT 系統」とする）は、現在のと ころ感染態 3 期幼虫および雄成虫の尾部の形態か らS. kushidai と同種である可能性が高いことが 
報告されている。ここでは KTY 系統線虫の共生 細菌について生理・生化学的性質並びに殺虫活性 を S. kushidai の共生細菌（以下「SK 菌」とする） と比較することによって各細菌の相同性を調査し た。その結果、KTY 線虫の共生細菌は SK 菌同 様、大型桿菌でフィラメント状の菌体が多く見ら れ、形態学的な特徵は一致した。また、SK 菌が特 異的に産生する金属光沢を有する結晶物が KTY 系統の共生細菌でも認められた。一般的な生理・ 生化学的な性質もほぼ同様の傾向が認められたが、 KTY 共生細菌はリパーゼ活性において SK 菌よ りも優れていた。現在、各細菌の糖の酸化能・炭
素源の資化能について比較調査中である。両系統 の線虫ともセマダラコガネ 3 齢幼虫に対して殺虫 活性を有するが、KTY 系統の方が殺虫に至るま での日数が若干長かった。これらの共生細菌につ いてセマダラコガネ幼虫に対する殺虫活性を調查 中である。また、各共生細菌のハスモンヨトウ終 齢幼虫に対する殺虫活性を血体腔内注射法により 調查したところ、各細菌とも50１0,000 cells/ insect の接種濃度で死亡は認められなかった。今 後更に、数種昆虫に対する殺虫活性について比較 検討し、線虫自身の感染性と共生細菌の殺虫活性 について考察する。 